\title{
DETERMINING FACTORS OF TEACHERS' SELF-EFFICACY IN COUNTRIES OF THE EUROPEAN UNION. RESULTS FROM TALIS 2013
}

(FACTORES DETERMINANTES DE LA AUTOEFICACIA DOCENTE EN LOS PAÍSES DE LA UNIÓN EUROPEA. RESULTADOS A PARTIR DE TALIS 2013)

Inmaculada Egido Gálvez

Universidad Complutense de Madrid

Esther López-Martín

UNED

Jesús Manso

Javier M. Valle

Universidad Autónoma de Madrid

DOI: $10.5944 / e d u c X X 1.15875$

Cómo referenciar este artículo/How to reference this article:

Egido Gálvez, I.; López-Martín, E.; Manso, J. \& Valle, J.M. (2018). Determining factors of teachers' self-efficacy in countries of the European Union. Results from TALIS 2013. Educación $X X 1,21(2), 225-248$, doi: 10.5944/educXX1.15875

Egido Gálvez, I.; López-Martín, E.; Manso, J. \& Valle, J.M. (2018). Determining factors of teachers' self-efficacy in countries of the European Union. Results from TALIS 2013. [Factores determinantes de la autoeficacia docente en los países de la Unión Europea. Resultados a partir de TALIS 2013]. Educación XX1, 21(2), 225-248, doi: 10.5944/educXX1.15875

\section{ABSTRACT}

Over the last few years, the effect that teachers' beliefs have on the results achieved by their students has been widely studied. Educational research has shown that the self-efficacy beliefs of teachers in their work influence their professional behavior and are associated with students' achievement and motivation. The main aim of this work is to study the personal and contextual factors determining the level of self-efficacy perceived by teachers in countries of the European Union which participated in TALIS 2013. Specifically, it attempts to answer the following questions: What are the main determinants of teachers' self-efficacy beliefs? Are these factors individual or contextual? Do these determinants vary from country to country? Taking into account the 
multistructural level of available data (teachers - Level 1- are nested within schools - Level 2- in each country), data analysis has been carried out by means of multilevel structural equation modeling. More specifically, a multigroup multilevel model has been designed to study the effect of teachers' traits (Level 1 predictors) and school traits (Level 2 predictors) on the perceived level of self-efficacy in different countries. The results show that variables relating to the teachers as professionals (cooperation with their colleagues, encouraging self-evaluation by the students, teachers' perception of satisfactory class discipline, a need for professional development in the contents of the subject taught and in teaching skills, and having a constructivist teaching approach) are the ones most closely related to their self-efficacy beliefs. These are more important than factors associated with the institutional setting in which they work (ownership, ratio, or shortage of resources), or strictly personal traits (age, gender, or work situation).

\section{KEYWORDS}

Self-efficacy beliefs; teachers; comparative analysis; multilevel structural equation modeling.

\section{RESUMEN}

En los últimos años, el efecto de las creencias de los profesores sobre los resultados obtenidos por sus alumnos ha sido ampliamente estudiado. La investigación educativa ha demostrado que las creencias de autoeficacia de los docentes en su trabajo influyen en su comportamiento profesional y están asociadas con el rendimiento y la motivación de los estudiantes. El objetivo principal de este trabajo es estudiar los factores personales y contextuales que determinan el nivel de autoeficacia percibida por los docentes en los países de la Unión Europea que participaron en TALIS 2013. En concreto, se trata de responder a las siguientes preguntas: ¿Qué variables determinan las creencias de autoeficacia de los docentes? ¿Se trata de factores de carácter individual o contextual? ¿Estos determinantes varían de un país a otro? Teniendo en cuenta el nivel agregado de los datos disponibles (los profesores -Nivel 1- se anidan dentro de las escuelas -Nivel 2- en cada país), el análisis de datos se ha llevado a cabo por medio de modelos de ecuaciones estructurales multinivel. Más específicamente, se ha estimado un modelo multinivel multigrupo para estudiar el efecto de las características de los profesores (predictores de Nivel 1) y de las escuelas (predictores de Nivel 2) en el nivel de percepción de autoeficacia en diferentes países. Los resultados muestran que las variables relativas a los profesores como profesionales (cooperación con sus colegas, fomento de la autoevaluación por parte de los estudiantes, percepción de una disciplina de aula satisfactoria, necesidad de desarrollo profesional en los contenidos de la materia enseñada y en las habilidades de enseñanza, así como un enfoque pedagógico constructivista) son las que se relacionan más estrechamente con sus creencias de autoeficacia. Estos factores son 
más importantes que los relacionados con el entorno institucional en el que trabajan (titularidad del centro, ratio o escasez de recursos) o con rasgos de carácter estrictamente personal (edad, sexo o situación laboral).

\section{PALABRAS CLAVE}

Creencias de autoeficacia; profesor; análisis comparativo; modelos de ecuaciones estructurales multinivel.

\section{INTRODUCTION}

Several years ago, the studies of Albert Bandura $(1977,1978)$ in the area of social cognitive theory started to investigate the concept of self-efficacy and found that people's actions are affected by the outcomes they expect to achieve. This area of research has become increasingly consolidated and there is now evidence to show that self-efficacy, understood as a belief in one's own ability to organize and carry out the actions required to achieve a specific goal (Bandura, 1978), is a mediator of behavior associated with personal motivation and, ultimately, with the success or failure of a task (Abroampa \& Wilson, 2013; Cubukcu, 2008; Gavora, 2010).

Studies into teachers' self-efficacy beliefs are not new in the field of educational research, especially ones focusing on the association between this construct, practices of the teaching staff, and the outcomes achieved by students. Hence, many initial studies relating to this topic show that teachers' beliefs in their own work constitute a predictive factor of their behavior, highlighting the important relationship between high levels of teachers' self-efficacy beliefs and greater student achievement (Anderson, Greene, \& Loewen, 1988; Ashton \& Webb, 1986; Henson, 2001; Midgley, Feldlaufer, \& Eccles, 1989). These findings are also confirmed in more recent studies (Bruce, Esmonde, Ross, Dookie, \& Beatty, 2010; Mahmoee \& Pirkamali, 2013), in which the relationship between teaching self-efficacy and academic performance has been comprehensively investigated and verified.

Teachers' self-efficacy is indirectly associated with students' achievements, as it affects the behavior of teachers in the classroom and the strategies they use to create adequate learning environments. More specifically, the level of competence teachers believe they have largely determines how they act with students and colleagues, their creativity at work, and the effort they invest to achieve good results (Caprara, Barbaranelli, Borgogni, \& Steca, 2003; Caprara et al., 2006; Guskey \& Passaro, 1994; Klassen \& Chiu, 2010; Van den Berg, 2002). In relation to their self-efficacy, 
teachers believe that they are capable, or not, of managing the class, teaching the students well and increasing the students' commitment and motivation.

In fact, previous studies have shown that teachers' self-efficacy beliefs are associated with their persistence in how they perform teaching activities, their commitment to supporting and improving students' learning (Abarza \& Ávila, 2012), and the degree of their involvement with students and other teachers (Ross, 1995). Teachers with the highest levels of selfefficacy have a greater tendency to try new strategies with their students (Guskey, 1988), and persevere for longer to look for solutions in the case of difficult teaching experiences or more complicated challenges (Coladaraci, 1992). Furthermore, Ashton and Webb (1986) found that teachers who believe in their own efficacy have high expectations for all their students, establish atmospheres in the classroom that encourage warm interpersonal relationships and foment greater academic rigor. Along the same lines, Prieto (2005) argues that teachers with a high self-efficacy belief are more open to new ideas, so they adapt their classes to suit their students' needs. These teachers tend to encourage students' autonomy and are more attentive of students with limited capacities. They are also less likely to suffer exhaustion (Ross \& Bruce, 2007). Ultimately, teachers with high self-efficacy beliefs have a greater trust in their students' ability (DaCosta \& Riordan, 1996).

Apart from focusing on the behavior of the teaching staff in the classroom and their relationship with students, research has also shed some light on their interactions in the school setting. The most effective teachers are the ones most likely to seek the help of other teaching staff (DeMesquita \& Drake, 1994; Henson, 2001), to adopt collaborative approaches with other teachers, such as team teaching (OECD, 2009) and to encourage parental participation in the education (Hoover-Dempsey, Bassler, \& Brissie, 1992). They also collaborate more at the school and adopt additional roles (Wheatley, 2005; Henson, 2001).

Teachers' self-efficacy beliefs are also associated with a greater personal satisfaction and a higher level of commitment to their profession, as these teachers tend to be more enthusiastic and are more dedicated to their work (Allinder, 1994; Chen, 2007; Evans \& Tribble, 1986; Labone, 2004; Prieto, 2005; Tschannen-Moran \& Hoy, 2001). Moreover, self-efficacy beliefs have been found to be important for controlling professional stress (Bangs \& Frost, 2012), making teachers less likely to leave the profession (Tschannen-Moran \& Hoy, 2001).

Given the importance of teachers' self-efficacy on students' learning outcomes and on the other dimensions of their professional work, it is not surprising that increasing emphasis is being placed on understanding the 
factors that determine this construct. To this end, over the past few years research has focused on analyzing the variables associated with teachers' levels of confidence in their own professional ability.

The personal characteristics of teachers that have been studied include age and gender. Some studies have shown that women manifest the highest levels of self-efficacy belief (Anderson, Greene, \& Loewen, 1988; Kiviet \& $\mathrm{Mji}, 2003)$, although the results are not conclusive, as this trend is not observed for all educational levels or for all areas of teaching. There is no clear concordance either in the studies that analyze variables such as age, or length of service in the teaching activity, while some studies show a positive relationship between these variables and self-efficacy belief (Lewandowski, 2005), others show the opposite (Hoy \& Woolfolk, 1990).

Another interesting line of research corresponds to the analysis of selfefficacy beliefs in relation to the development of their professional teaching career. Some authors suggest that teachers' self-efficacy beliefs tend to be low when they complete their initial training (Evans \& Tribble, 1986; Izadinia, 2014), and consider induction programs to be essential to increase beliefs in teaching self-efficacy (Elliott, Isaacs, \& Chugani, 2010). However, other studies, such as Klassen and Chiu (2010) have shown a positive relationship between professional experience and perceived self-efficacy during the development and maturation of teachers' careers, whereas this relationship becomes negative near the end of the professional career. Similarly, Pendergast, Garvis and Keogh (2011) show that self-efficacy greatly increases during the first few years after entering the teaching profession, but decreases again when teachers are approaching retirement.

Another factor that appears to affect perceived professional selfefficacy is the teachers' level of preparation, understood as the extent to which they feel they have the tools required to teach with efficacy (Prieto, 2005). The right training gives the teachers more confidence in their own ability to achieve good teaching outcomes (Ross, Bradley, \& Gadalla, 1996), which could also explain why teachers with a higher level of training tend to perceive themselves as having the highest efficacy (Hoy \& Woolfolk, 1993).

A noteworthy finding of the literature review is the limited research into the relationship between self-efficacy and variables relating to the school as a contextual setting in which teachers work. Hence, with the exception of a few studies that analyze factors such as the educational level the teachers work in (Prieto, 2005), the number of students in the class (OECD, 2009), or public or private ownership of the school (Abroampa \& Wilson, 2013), there are very few studies that focus on these issues. Moreover, the results of these studies are largely inconclusive, as no clear relationships 
were observed between the factors studied and self-efficacy beliefs. It is, therefore, necessary to study these matters in greater depth, not only taking into account variables directly related to the teachers and their performance, but also elements that constitute their working environment.

\section{PURPOSE OF STUDY}

In the light of the above, this paper aims to provide empirical evidence for the personal or contextual factors associated with teachers' professional work that determine the level of their self-efficacy beliefs. Specifically, it attempts to answer the following questions: What are the main determinants of teachers' self-efficacy beliefs? Are these factors individual or contextual? Do these determinants vary from country to country? To achieve this, the analysis was based on the results of TALIS 2013, which provides valuable information to expand our knowledge in this area. More specifically, two main objectives were pursued: 1) to study the factors determining the level of teaching efficacy perceived by teachers in countries of the European Union which participated in TALIS 2013, including both personal and contextual variables traditionally ignored in studies of this type; 2 ) to establish possible differences in these determinants of self-efficacy belief in relation to the participating country, or, by contrast, to determine whether the countries share these conditioning variables. In spite of the limitations of comparing different educational realities (Ball, 2013), with international datasets such as those offered by TALIS, a wide range of indices and variables can be analyzed, making it possible to explore aspects largely overlooked in previous studies (Phillips \& Schweisfurth, 2014).

\section{METHOD}

\section{Sample}

The TALIS study, conducted by the OECD, is a large-scale assessment aimed at providing information about teaching conditions and learning environments in schools. In the second edition, carried out in 2013, the target population corresponded to teachers and principals in compulsory secondary education (ISCED Level 2). The sample was selected by means of a two-stage design, in which schools were the first-stage units and teachers corresponded to the second-stage units. In each of the 34 participating countries, a total of 200 schools and 20 teachers from each school were selected (OECD, 2013). 
Table 1 shows the final number of schools and teachers from the 17 countries of the European Union that participated in TALIS 2013, which constitute the study sample considered in this work. The sample is composed of 51,025 teachers from 3021 schools.

Table 1

Composition of the sample

\begin{tabular}{lcc}
\hline \multicolumn{1}{c}{ Country } & Schools & Teachers \\
\hline Belgium (Flanders) & 168 & 3.129 \\
Bulgaria & 197 & 2.975 \\
Croatia & 199 & 3.675 \\
Czech Republic & 220 & 3.219 \\
Denmark & 148 & 1.649 \\
Estonia & 197 & 3.129 \\
Finland & 146 & 2.739 \\
France & 204 & 3.002 \\
Italy & 194 & 3.337 \\
Latvia & 116 & 2.126 \\
The Netherlands & 127 & 1.912 \\
Poland & 195 & 3.858 \\
Portugal & 185 & 3.628 \\
Slovak Republic & 193 & 3.493 \\
Spain & 192 & 3.339 \\
Sweden & 186 & 3.319 \\
United Kingdom (England) & 154 & 2.496 \\
\hline
\end{tabular}

Source: Prepared by the authors, based on OECD (2014a)

\section{Variables}

The response variable corresponded to the self-efficacy belief index measured in the TALIS study. This index has been calculated from the mean of the scores estimated for teachers in the following three indices ${ }^{1}$ : 1) Efficacy in classroom management (SECLSS); 2) Efficacy in instruction (SEINSS); 3) Efficacy in student engagement (SEENGS). The mean of the above efficacy indices is 10 and the standard deviation is 2. Regarding the construction of this index, it is noteworthy that although teacher selfefficacy belief was also assessed in TALIS 2008, in this new version the measure was expanded to include different aspects of teacher self-efficacy ${ }^{2}$ relating to the three previous scales (OECD, 2013). The index of self-efficacy 
reliability was calculated from the reliabilities of these three indices. and the alpha reliability coefficients were higher than 0.70 for these scales in most countries (See Table 2 for the 17 countries of the European Union that participated in TALIS 2013). The overall international reliabilities were: $\alpha=0.843$ for SECLSS, $\alpha=0.794$ for SEINSS, and $\alpha=0.830$ for SEENGS. The internal structure of the scales was examined with a confirmatory factor analysis (CFA) model for each of the countries, and the results of this analysis were largely acceptable (OECD, 2014b).

Table 2

Alpha reliability coefficient for the SECLSS, SEINSS and SEENGS scales (ISCED Level 2)

\begin{tabular}{lccc}
\hline \multicolumn{1}{c}{ Country } & SECLSS & SEINSS & SEENGS \\
\hline Belgium (Flanders) & 0.853 & 0.684 & 0.776 \\
Bulgaria & 0.724 & 0.763 & 0.720 \\
Croatia & 0.838 & 0.735 & 0.740 \\
Czech Republic & 0.832 & 0.721 & 0.766 \\
Denmark & 0.797 & 0.715 & 0.756 \\
Estonia & 0.785 & 0.738 & 0.726 \\
Finland & 0.845 & 0.768 & 0.818 \\
France & 0.803 & 0.634 & 0.753 \\
Italy & 0.782 & 0.745 & 0.768 \\
Latvia & 0.792 & 0.703 & 0.726 \\
The Netherlands & 0.852 & 0.646 & 0.740 \\
Poland & 0.817 & 0.758 & 0.770 \\
Portugal & 0.809 & 0.747 & 0.762 \\
Slovak Republic & 0.806 & 0.769 & 0.786 \\
Spain & 0.821 & 0.746 & 0.801 \\
Sweden & 0.836 & 0.725 & 0.741 \\
United Kingdom (England) & 0.841 & 0.768 & 0.818 \\
\hline
\end{tabular}

Source: Prepared by the authors, based on OECD (2014b, pp. 197-198)

On the other hand, predictors corresponding to the personal and professional characteristics of the teachers, or characteristics of the schools in which the teachers work, were considered to possibly influence perceived levels of self-efficacy. The predictors chosen are those included in the questionnaires completed by teachers and principals in the TALIS-2013 study, as shown in Table 3. 
Table 3

Operationalization of variables

\begin{tabular}{|c|c|}
\hline \multicolumn{2}{|r|}{ Questionnaire for teachers } \\
\hline Gender & $\begin{array}{l}0=\text { Woman } \\
1=\text { Man }\end{array}$ \\
\hline Years of experience & Total number of years working as a teacher \\
\hline Working hours & $\begin{array}{l}0=\text { More than } 90 \% \text { of full-time hours } \\
1=\text { From } 71 \% \text { to } 90 \% \text { of full-time hours } \\
2=\text { From } 50 \% \text { to } 70 \% \text { of full-time hours } \\
3=\text { Less than } 50 \% \text { full-time hours }\end{array}$ \\
\hline $\begin{array}{l}\text { Participation in } \\
\text { professional induction } \\
\text { programs }\end{array}$ & $\begin{array}{l}\text { The teacher participates in none, one, two or three of } \\
\text { the following activities designed to support teachers } \\
\text { at the start of their career: 'Professional induction } \\
\text { program', 'informal induction activities' and 'General } \\
\text { professional induction program and/or induction } \\
\text { program run by the center' }\end{array}$ \\
\hline Constructivist beliefs & $\begin{array}{l}\text { Index with a mean of } 10 \text { and standard deviation } \\
\text { of } 2 \text {, which informs about the personal beliefs in } \\
\text { constructivist teaching and learning. }\end{array}$ \\
\hline Teacher co-operation & $\begin{array}{l}\text { Index with a mean of } 10 \text { and standard deviation of } \\
2 \text {, which informs about the frequency with which } \\
\text { teachers collaborate with activities and exchange } \\
\text { experiences }\end{array}$ \\
\hline $\begin{array}{l}\text { In-service education } \\
\text { and training }\end{array}$ & $\begin{array}{l}\text { Participation in activities aimed at developing } \\
\text { teaching skills: } \\
0=\text { Does not participate } \\
1=\text { Participates }\end{array}$ \\
\hline $\begin{array}{c}\text { Need for professional } \\
\text { development }\end{array}$ & $\begin{array}{l}\text { Index with a mean of } 10 \text { and standard deviation } \\
\text { of } 2 \text { that informs about the need for professional } \\
\text { development in the contents of the subject taught and } \\
\text { in teaching skills. }\end{array}$ \\
\hline $\begin{array}{l}\text { Students' self-evaluation } \\
\text { of learning process }\end{array}$ & $\begin{array}{l}\text { Frequency ( } 0: \text { Never or almost never - } 4: \text { In all } \\
\text { or almost all classes }) \text { the teacher encourages the } \\
\text { students to assess their own learning }\end{array}$ \\
\hline Perceived class discipline & $\begin{array}{l}\text { Index with a mean of } 10 \text { and standard deviation } \\
\text { of } 2 \text { that informs about the teachers perception of } \\
\text { satisfactory class discipline. }\end{array}$ \\
\hline
\end{tabular}




\begin{tabular}{c|l}
\hline \multicolumn{2}{c}{ Questionnaire for Center } \\
\hline Ownership & $\begin{array}{l}\mathbf{0}=\text { Public } \\
\mathbf{1}=\text { Private }\end{array}$ \\
\hline Ratio & $\begin{array}{l}\text { Index resulting from dividing the total number of } \\
\text { students in the school by the number of teachers }\end{array}$ \\
A shortage of human resources at the school: \\
$\begin{array}{c}\text { Lack of pedagogical } \\
\text { personnel }\end{array}$ & $\begin{array}{l}1=\text { Problematic to a degree } \\
2=\text { It is a problem }\end{array}$ \\
A shortage of material resources in the school: \\
$0=$ Not a problem \\
$1=$ Problematic to a degree \\
$2=$ It is a problem
\end{tabular}

From the table above, it can be observed that two dummy variables have been created (1. teachers who participate in activities aimed at developing teaching skills; 2 . privately owned schools). It will thus be possible to analyze the differential effect of participating in these activities and to work in private schools on teacher self-efficacy beliefs. In relation to the variables Lack of pedagogical personnel and Lack of material, both were recorded so that schools where the shortage of human and material resources is not a problem should be considered as the reference category.

\section{Data analysis}

Taking into account the multistructural level of available data (teachers - Level 1-are nested within schools - Level 2 - in each country), the effect of level 1 and level 2 predictors on levels of self-efficacy perceived by the teachers has been estimated with multigroup multilevel structural equation models (Muthén, 1994; Muthén, Khoo, \& Gustafsson, 1997).

Hence, in the first place a two-level multiple group CFA was defined, in which the variance of the dependent variable (self-efficacy belief index) was decomposed into a teacher (within) component and a school (between) component. This enabled differences between teacher self-efficacy beliefs (Level 1) and differences among the schools in the mean self-efficacy beliefs of their teachers (Level 2) to be analyzed. Next, another model was estimated in which indicators relating to both teachers and schools were introduced 
as covariates. With this model, it was possible to establish the extent to which the level 1 and level 2 predictors can be considered as determinants of teachers' self-efficacy beliefs in each country.

Estimation of the different multilevel models was carried out using the maximum likelihood estimator with robust standard errors (MLR) and the Mplus software (Muthén \& Muthén, 1998-2010). It is important to note that in order to obtain unbiased estimates in the calculation of the models, different sets of weighted samples were used (OECD, 2014b).

\section{RESULTS}

\section{Null model}

Table 4 presents the results obtained after estimating the model without contextual covariates (null model). This model can be considered a just-identified model, since all the possible parameters are being estimated. In this type of models, the degrees of freedom are zero $\left(\chi^{2}=0.000, \mathrm{df}=0\right)$ and the fit indices always indicate a perfect fit $(\mathrm{RMSEA}=0.000 ; \mathrm{CFI}=1.000$; and TLI $=1.000$ ). In any case, these indices cannot be used to determine the goodness of fit of the just-identified models. In this sense, it is important to note that the judgment of the model fit of these models «focuses more on the estimated model parameters (...) and the obtained proportion of the explained variability in the endogenous variables (...) rather than the global fit statistic output» (Geiser, 2013, p. 67).

The second column of the table shows the mean level of teachers' self-efficacy beliefs in each of the countries studied. These values are represented in Figure 1, together with the 95\% confidence interval. Therefore, this not only shows the position of each country in relation to the others, but also whether the differences among them are statistically significant. Taking into account that the mean level of self-efficacy for all the individuals participating in the TALIS 2013 study equals 12.45 points, we can see that the self-efficacy belief of teachers in Bulgaria, Belgium, the Slovak Republic, France, Italy, the United Kingdom, Denmark, and Portugal are above this value, and in Portugal it is remarkably high (13.8 points). On the other hand, Sweden, Latvia, Poland, Spain, Finland, the Netherlands, Croatia, Estonia, and the Czech Republic have lower than average self-efficacy beliefs, with the Czech Republic presenting the lowest value of all (10.8 points). Many of the differences among the countries are statistically significant ${ }^{3}$ and two groups of countries can be distinguished: those with an above average self-efficacy belief in TALIS-2013, and those with a below average value. 
Table 4

Null model

\begin{tabular}{|c|c|c|c|c|c|}
\hline & \multirow{2}{*}{ Self-efficacy } & \multirow{2}{*}{$\begin{array}{c}\text { Between-teacher } \\
\text { variance }\end{array}$} & \multirow{2}{*}{$\begin{array}{l}\text { Between-school } \\
\text { variance }\end{array}$} & \multicolumn{2}{|c|}{$\begin{array}{c}\text { Percentage of } \\
\text { unexplained variance }\end{array}$} \\
\hline & & & & $\begin{array}{l}\text { Level } 1 \\
\text { (Teacher) }\end{array}$ & $\begin{array}{c}\text { Level 2 } \\
\text { (School) }\end{array}$ \\
\hline Belgium & $12.750(0.035) * *$ & $2.035(0.062)^{* * *}$ & $0.016(0.024)$ & $100.0 \%$ & $0.0 \%$ \\
\hline Bulgaria & $12.637(0.044)^{* * *}$ & $1.861(0.068)^{* * *}$ & $0.115(0.034)^{* * *}$ & $94.2 \%$ & $5.8 \%$ \\
\hline Croatia & $11.831(0.035) * *$ & $2.084(0.067)^{* * *}$ & $0.035(0.022)$ & $100.0 \%$ & $0.0 \%$ \\
\hline Czech R. & $10.811(0.039)^{* * *}$ & $2.467(0.075)^{* * *}$ & $0.089(0.033)^{* * *}$ & $96.5 \%$ & $3.5 \%$ \\
\hline Denmark & $13.327(0.050) * *$ & $1.732(0.077) * *$ & $0.061(0.035)$ & $100.0 \%$ & $0.0 \%$ \\
\hline Estonia & $11.573(0.034) * *$ & $2.392(0.078)^{* * *}$ & $0.013(0.021)$ & $100.0 \%$ & $0.0 \%$ \\
\hline Finland & $11.872(0.049)^{* *}$ & $3.203(0.106)^{* * *}$ & $0.060(0.034)$ & $100.0 \%$ & $0.0 \%$ \\
\hline France & $12.831(0.036) * *$ & $1.678(0.060)^{* * *}$ & $0.034(0.022)$ & $100.0 \%$ & $0.0 \%$ \\
\hline Italy & $13.096(0.034) * *$ & $1.760(0.051)^{* * *}$ & $0.034(0.022)$ & $100.0 \%$ & $0.0 \%$ \\
\hline Latvia & $12.087(0.043)^{* *}$ & $1.799(0.060)^{* * *}$ & $0.075(0.035)^{*}$ & $96.0 \%$ & $4.0 \%$ \\
\hline Netherlands & $11.861(0.048)^{* *}$ & $2.019(0.090)^{* * *}$ & $0.071(0.045)$ & $100.0 \%$ & $0.0 \%$ \\
\hline Poland & $12.032(0.039) * *$ & $2.426(0.064)^{* * *}$ & $0.100(0.030)^{*}$ & $96.0 \%$ & $4.0 \%$ \\
\hline Portugal & $13.775(0.031)^{* * *}$ & $1.631(0.049)^{* * *}$ & $0.027(0.017)$ & $100.0 \%$ & $0.0 \%$ \\
\hline Slovak R. & $12.766(0.041)^{* *}$ & $2.154(0.076) * *$ & $0.096(0.028)^{*}$ & $95.7 \%$ & $4.3 \%$ \\
\hline Spain & $12.002(0.041) * *$ & $2.651(0.071)^{* *}$ & $0.074(0.038)^{*}$ & $97.3 \%$ & $2.7 \%$ \\
\hline Sweden & $12.159(0.049)^{* *}$ & $2.420(0.084)^{* * *}$ & $0.147(0.044)^{*}$ & $94.3 \%$ & $5.7 \%$ \\
\hline UK & $13.103(0.049)^{* *}$ & $2.627(0.096) * *$ & $0.109(0.041) *$ & $96.0 \%$ & $4.0 \%$ \\
\hline
\end{tabular}

* Significant at $\alpha=0.05$ level * Significant at $\alpha=0.01$ level

Note $_{1}$ : Standard error in brackets

Note $_{2}$ : The percentage of unexplained variance refers to the amount of the total variance (Between-teacher and between-school) that is located in each level

If we observe the random part of the model, the between-teacher variance is significant in all cases. It would, therefore, be recommendable to expand the model, introducing predictors that can help to explain these differences. However, on examination of the between-school variance, this parameter is only significant in Bulgaria, the Czech Republic, Latvia, Poland, Slovak Republic, Spain, Sweden, and the United Kingdom. In all the other countries, the levels of teachers' self-efficacy beliefs do not vary between the schools. It is noteworthy that, even in the cases with significant between-school variance, approximately $95 \%$ of the variance is located around Level 1 (Teacher). 


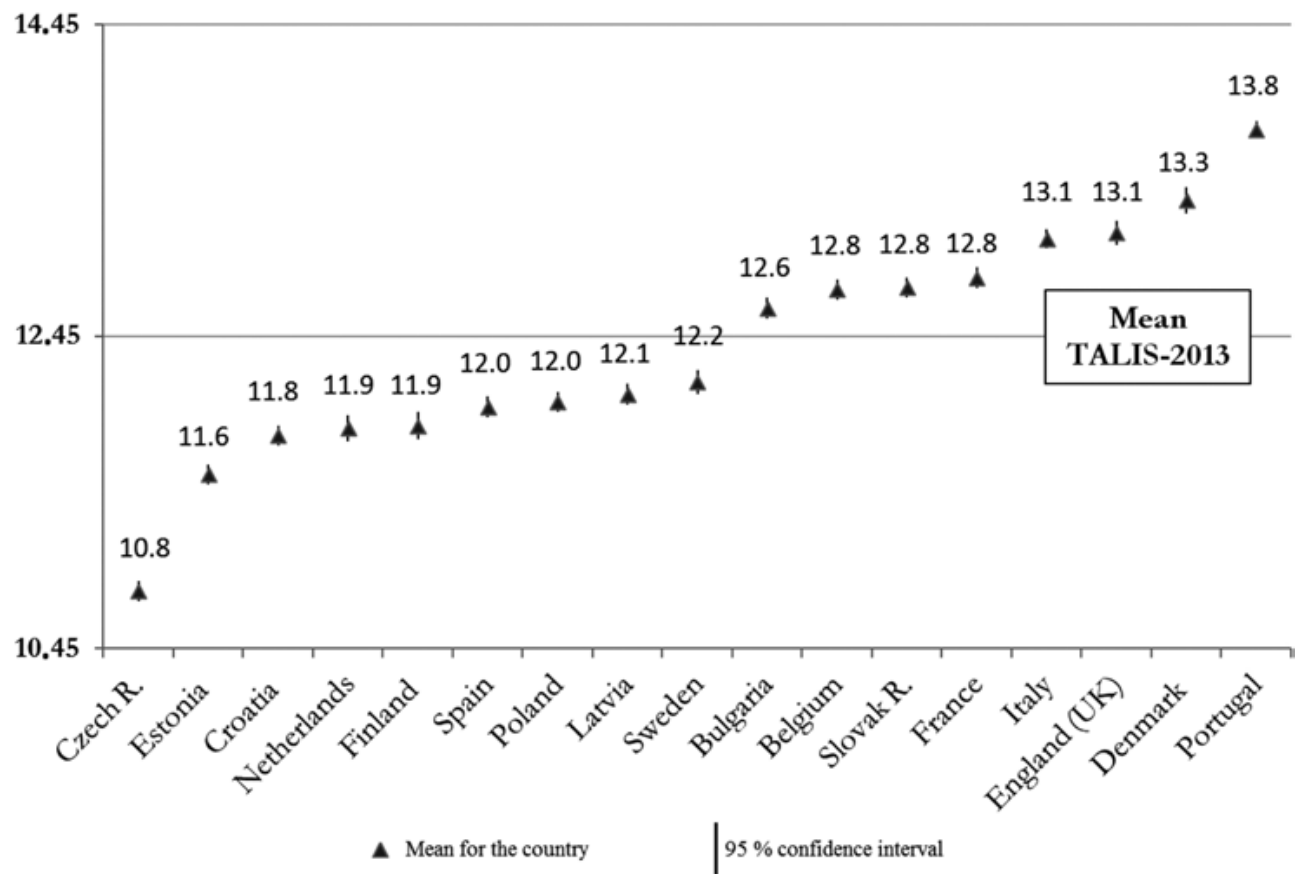

Figure 1. Teachers' self-efficacy beliefs in countries of the European Union

\section{Model with contextual covariates}

After introducing covariates associated with teachers (Level 1) and schools (Level 2), the results of the estimated model are included in Table 5. In this case, it is also a just-identified model with zero degrees of freedom $\left(\chi^{2}=89.869, \mathrm{df}=0, \mathrm{p} .<0.05\right)$. The other fit indices reflect a good fit of the model to the data $(\mathrm{RMSEA}=0.000, \mathrm{CFI}=0.986, \mathrm{y}$ TLI $=1.000)$ although, as indicated above, this information cannot be used to determine how well the model fits. When the two models are compared by Akaike's Information Criterion (AIC) and the Bayesian Information Criterion (BIC), the latter model has the lowest AIC and BIC statistics (AIC $=107715.142 ; \mathrm{BIC}=$ 110129.712) and, consequently, fits better than the model that does not include the covariates $($ AIC $=114293.769 ; \mathrm{BIC}=114719.869)$.

From the results, teachers' self-efficacy is observed to vary in relation to the individual and contextual factors considered. In turn, we find that some differences in factors are significant in every country studied. It is, therefore, possible to distinguish between contextual covariates that seem to have a significant effect on the level of self-efficacy perceived by all the teachers in the sample, and other indicators for which the effect is only significant in some of the countries. 


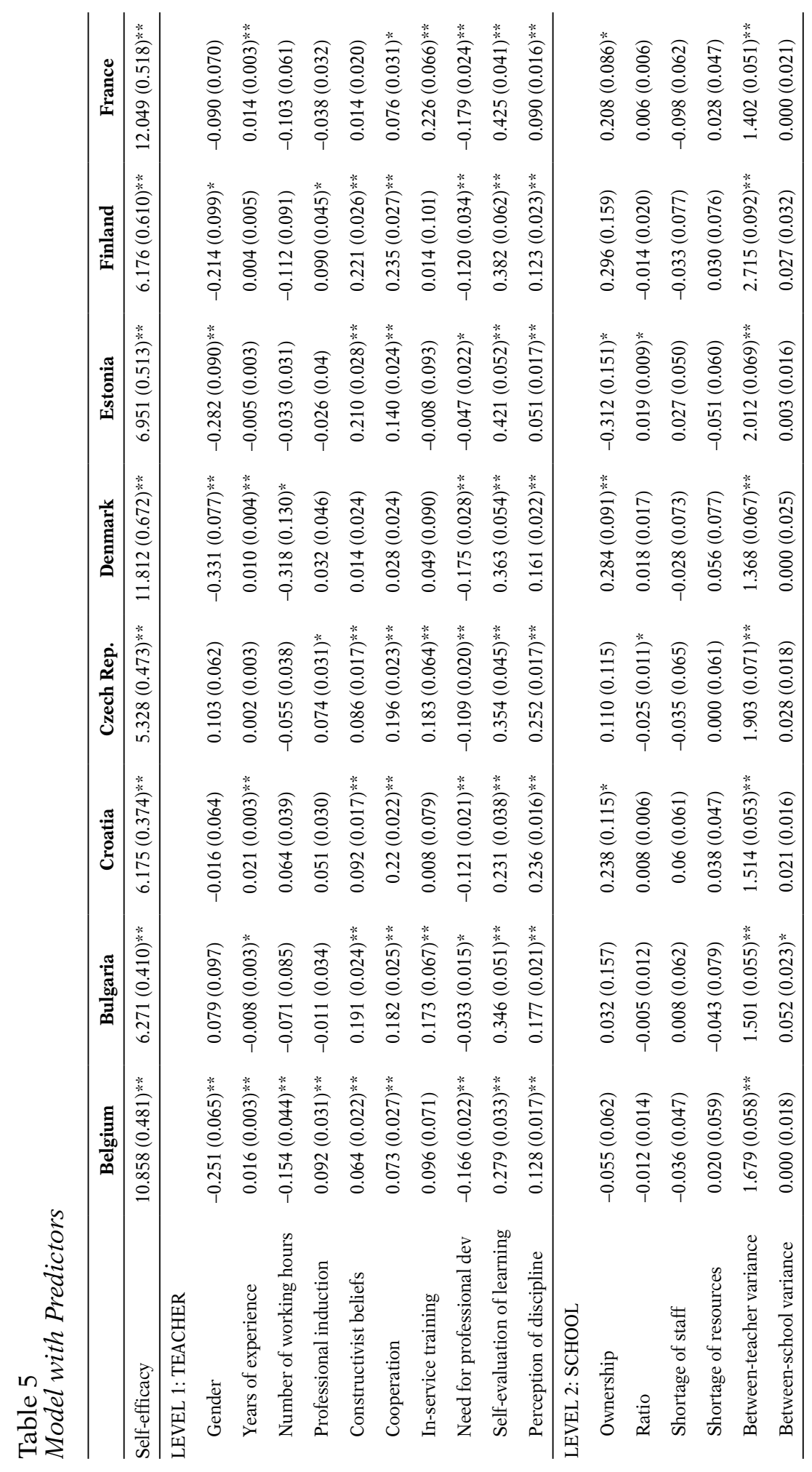




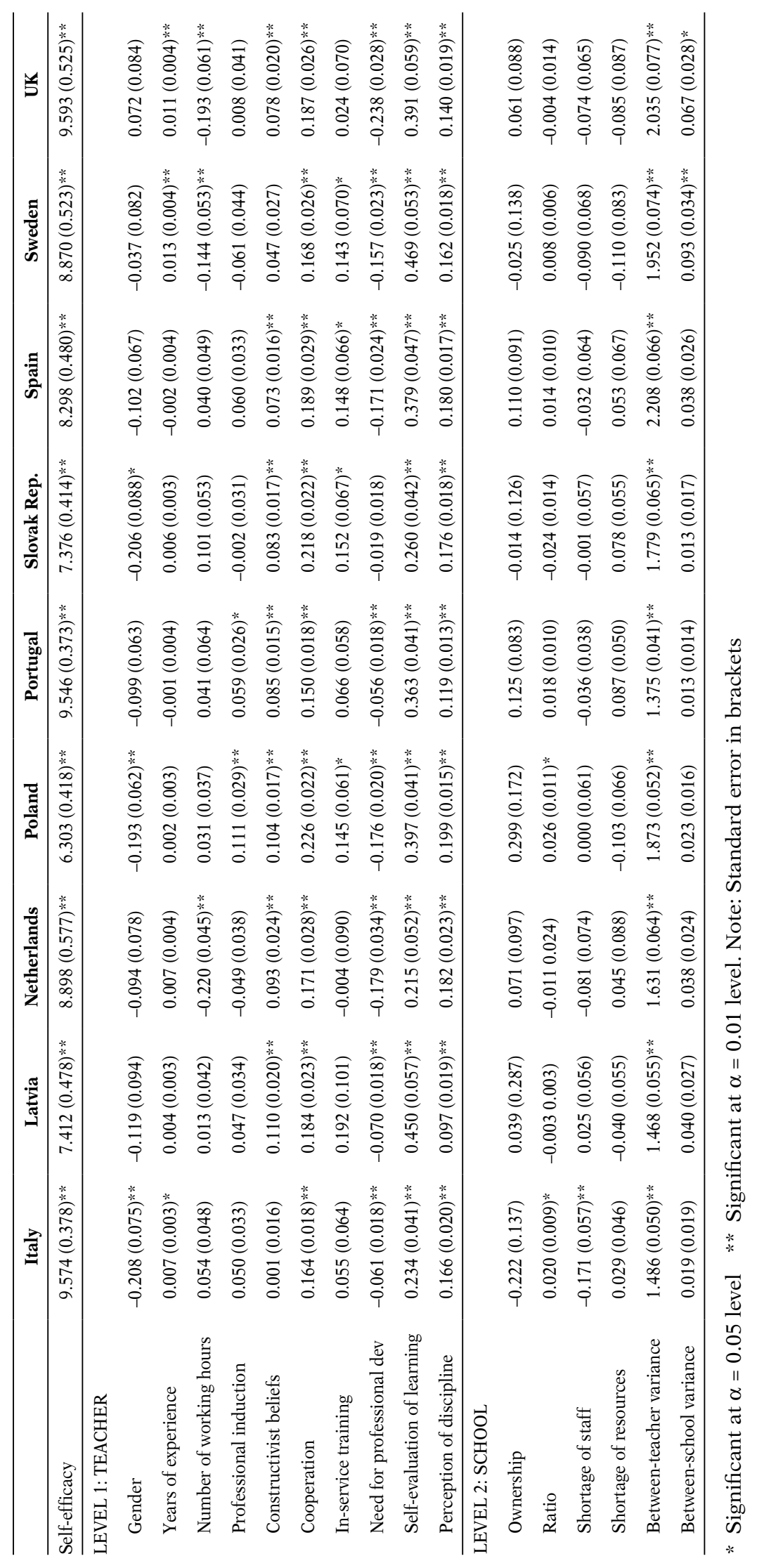


The first group shows the positive effect of the students' involvement in the evaluation process and the perception of satisfactory classroom discipline on self-efficacy belief. This category could also include the positive effect, with the exception of Denmark, of cooperation between teachers, the negative effect, with the exception of Slovak Republic, of the need for professional development, and the positive effect, with the exception of Denmark, France, Italy and Sweden, of the personal beliefs in constructivist teaching and learning.

Certain determinants of teachers' sense of self-efficacy only appear in some countries, such as gender (male teachers believe themselves to have less efficacy than their female colleagues in Belgium, Denmark, Estonia, Finland, Italy, Poland, and the Slovak Republic), years of experience (with a positive influence of this variable in Belgium, Croatia, Denmark, France, Italy, Sweden, and the United Kingdom, but negative in Bulgaria), working hours (teachers working part-time consider themselves to have less efficacy than full-time teachers in Belgium, Denmark, the Netherlands, Sweden, and the United Kingdom), participation in professional induction activities (has a positive effect in Belgium, the Czech Republic, Finland, Poland, and Portugal) and participation in recent years in in-service teacher-training activities (teachers participating in these types of activities consider themselves to present a higher efficacy than those who do not participate in Bulgaria, the Czech Republic, France, Poland, Slovak Republic, Spain, and Sweden).

The effect of predictors associated with the school level on teachers' self-efficacy beliefs is only significant in some countries. This is in accordance with the results presented in the null model, which shows between-school variances close to zero. Ownership of the school is one of the school variables that influences the teachers' perceived self-efficacy in Croatia, Denmark, Estonia, and France. However, while teachers in private schools in Croatia, Denmark, and France have a higher self-efficacy belief than teachers in state schools in these countries, in Estonia, the latter teachers have the higher self-efficacy beliefs. The influence of the student-teacher ratio on teachers' self-efficacy beliefs also varies among countries; hence, while the effect of this variable is negative in the Czech Republic, in Estonia, Italy and Poland teachers in schools with the highest ratios had the highest sense of selfefficacy. Finally, the shortage of staff in Italy was found to have a negative effect on teachers' self-efficacy beliefs.

In relation to the random part of the model, Table 6 records the proportion of variance associated with teacher (Level 1) and school (Level 2) levels explained after introducing covariates in the model. This also includes the proportion of variance that the response variable (teachers' self-efficacy) contributes to explaining these predictors (Snijders and Bosker, 1994). 
Table 6

Explained variance

\begin{tabular}{|c|c|c|c|c|c|c|}
\hline \multirow[b]{3}{*}{ Belgium } & \multicolumn{6}{|c|}{ Explained variance $\left(\mathbf{R}^{2}\right)$} \\
\hline & \multicolumn{2}{|c|}{$\begin{array}{c}\text { Level } 1 \\
\text { (Teacher) }\end{array}$} & \multicolumn{2}{|c|}{$\begin{array}{c}\text { Level } 2 \\
\text { (School) }\end{array}$} & \multicolumn{2}{|c|}{$\begin{array}{c}\text { Teachers' } \\
\text { self-efficacy }\end{array}$} \\
\hline & 0.175 & $(17.5 \%)$ & & & 0.175 & $(17.5 \%)$ \\
\hline Bulgaria & 0.193 & $(19.3 \%)$ & 0.548 & $(54.8 \%)$ & 0.214 & $(21.4 \%)$ \\
\hline Croatia & 0.274 & $(27.4 \%)$ & & & 0.274 & $(27.4 \%)$ \\
\hline Czech R. & 0.229 & $(22.9 \%)$ & 1.000 & $(100.0 \%)$ & 0.255 & $(25.5 \%)$ \\
\hline Denmark & 0.210 & $(21.0 \%)$ & & & 0.210 & $(21.0 \%)$ \\
\hline Estonia & 0.159 & $(15.9 \%)$ & & & 0.159 & $(15.9 \%)$ \\
\hline Finland & 0.152 & $(15.2 \%)$ & & & 0.152 & $(15.2 \%)$ \\
\hline France & 0.164 & $(16.4 \%)$ & & & 0.164 & $(16.4 \%)$ \\
\hline Italy & 0.156 & $(15.6 \%)$ & & & 0.156 & $(15.6 \%)$ \\
\hline Latvia & 0.184 & $(18.4 \%)$ & 1.000 & $(100.0 \%)$ & 0.217 & $(21.7 \%)$ \\
\hline Netherlands & 0.192 & $(19.2 \%)$ & & & 0.192 & $(19.2 \%)$ \\
\hline Poland & 0.228 & $(22.8 \%)$ & 1.000 & $(100.0 \%)$ & 0.259 & $(25.9 \%)$ \\
\hline Portugal & 0.157 & $(15.7 \%)$ & & & 0.157 & $(15.7 \%)$ \\
\hline Slovak R. & 0.174 & $(17.4 \%)$ & 1.000 & $(100.0 \%)$ & 0.209 & $(20.9 \%)$ \\
\hline Spain & 0.167 & $(16.7 \%)$ & 1.000 & $(100.0 \%)$ & 0.190 & $(19.0 \%)$ \\
\hline Sweden & 0.193 & $(19.3 \%)$ & 0.367 & $(36.7 \%)$ & 0.203 & $(20.3 \%)$ \\
\hline UK & 0.225 & $(22.5 \%)$ & 0.385 & $(38.5 \%)$ & 0.232 & $(23.2 \%)$ \\
\hline
\end{tabular}

It can be observed that the predictors included in the model explain an important percentage of the differences in the levels of teachers' selfefficacy beliefs. This ranges from $15.6 \%$ in Italy to $27.4 \%$ in Croatia. In countries with significant between-school variances, these differences can be explained by the individual and contextual characteristics considered (with the exception of Bulgaria, Sweden, and the United Kingdom).

\section{CONCLUSIONS AND DISCUSSION}

In the light of these results, it can be concluded that teachers from the different European countries participating in TALIS present significantly different self-efficacy beliefs. In spite of this difference, which could logically be attributed to socio-educational, cultural or historical variations among them (European Commission-Eurydice, 2015), a series of variables associated with teachers' self-efficacy beliefs in most of these countries has been identified. This set of variables could, therefore, constitute a common substrate to how European teachers perceive their self-efficacy. This would, mainly, be based on teachers' professional traits such as the students' 
involvement in the evaluation process and the perception of satisfactory classroom discipline, cooperation between teachers, the sense of having an appropriate career development and beliefs in constructivist teaching and learning.

By contrast, variables relating to teachers' personal characteristics (age, gender or work situation) only appear to be related to teachers' self-efficacy beliefs in some countries. Moreover, in these countries the variables do not follow a standard pattern. This could, perhaps, explain the lack of conclusive evidence in the current literature, as mentioned in the Introduction, for a relationship between personal factors and teachers' self-efficacy beliefs. From the international perspective of this research, these personal factors have been found to be of limited importance in explaining teachers' selfefficacy.

As with the variables associated with teachers' personal traits, variables related to the schools (ownership: state/private, student-teacher ratio and shortage of staff) are, also, only significant in a few countries and, once again, the behavior of these variables is not standard.

To sum up, it appears, from an international perspective, that factors related to the professional characteristics of the teachers are more closely related to self-efficacy beliefs than personal and school context factors.

Given the possibility of being able to intervene in teachers' professional characteristics, there is an opportunity to design actions targeted at improving these through educational policies and initial and refresher training. This could increase the level of teachers' perceived self-efficacy which, in turn, would improve the quality of the teaching imparted.

\section{LIMITATIONS}

Any international database (such as TALIS) offers great possibilities for statistical exploitation. However, caution must be exercised when working with the type of data studied here. On the one hand, the information is based on the responses in questionnaires completed by the subjects themselves, so will inevitably be impregnated with a subjective perception of the real situation.

Although this study is limited to studying the relationship among variables, identification of the variables most closely linked to perceived self-efficacy provides an opportunity to conduct research that could help to establish possible cause-effect relationships. 
Since this is an international study, owing to the diversity of each of the national units in relation to their cultural, social, political and educational characteristics, the conclusions drawn about differences or similarities among countries require contextual interpretations to be fully understood; not to mention inter-country variations that cast doubt on the accuracy of defining a single truth to represent a whole country.

Nonetheless, taking into account the limitations mentioned above, this work sheds some light on the factors that determine teachers' selfefficacy beliefs, at least in a European setting. Questions that remain to be answered provide us with opportunities to explore an area of apparently great potential in educational research (Scheerens, 2010).

\section{NOTES}

1 For more information about construction of the indices, consult the technical report of the TALIS 2013 study (OECD, 2014b).

2 The questionnaires in this study were devised by the Instrument Development Expert Group (IDEG) appointed by the OECD Secretariat and the self-efficacy scale was constructed with the help of Dr. Mareike Kunter from the University of Frankfurt (Germany) (OECD, 2014b).

3 The purpose of this study is to compare determinants of self-efficacy among countries, for which a two-level multiple group CFA has been estimated. However, a three-level CFA, in which the third level corresponds to the countries, presents a significant variance at this level, representing $18.5 \%$ of the unexplained variance. 


\section{REFERENCES}

Abarza, L.E., \& Avila, E.C. (2012). Creencias de Autoeficacia de Docentes de la Universidad Autónoma de Chile and su Relación con los Resultados de la Evaluación Docente. Revista de Psicología UVM, 2(4), 33-56.

Anderson, R.N., Greene, M.L., \& Loewen, P.S. (1988). Relationships among teachers' and students' thinking skills, sense of efficacy, and student achievement. The Alberta Journal of Educational Research, 34(2), 148-165.

Ashton, P.T., \& Webb, R.B. (1986). Making a difference: Teachers' sense of efficacy and student achievement. New York: Longman.

Abroampa, W.K., \& Wilson, K.N. (2013). Teachers' self-efficacy on school improvement: A comparative analysis of private and public junior high schools in the Takoradi Metropolis (Ghana). US-China Education Review, 3(12), 903-913.

Allinder, R. (1994). The relationship between efficacy and the instructional practices of special education teachers and consultants. Teacher Education and Special Education, 17, 86-95.

Bandura, A. (1977). Self-efficacy: Toward a unifying theory of behavior change. Psychological Review, 84, 191-215.

Bandura, A. (1978). Reflections on selfefficacy. Advances in Behaviour Research and Therapy, 1, 237-269.

Bandura, A. (1997). Self-efficacy: The exercise of control. New York: Freeman.

Bangs, J., \& Frost, D. (2012). Teacher self-efficacy, voice and leadership: towards a policy framework for education international. University of Cambridge Education International Research Institute. Retrieved from http://bit.ly/2jR0gm5

Ball, S. (2013). The education debate $\left(2^{\text {nd }}\right.$ ed.). Great Britain: Policy Press.

Bruce, C.D., Esmonde, I., Ross, J., Dookie, J., \& Beatty, R. (2010). The effects of sustained classroom-embedded teacher professional learning on teacher efficacy and related student achievement. Teaching and Teacher Education, 26(8), 1598-1608.

Caprara, G.V., Barbaranelli, C., Borgogni, L., \& Steca, P. (2003). Efficacy Beliefs as Determinants of Teachers Job Satisfaction, Journal of Educational Psychology, 95(4), 821-832.

Caprara, G.V., Barbaranelli, C., Steca, P \& Malone, P.S. (2006). Teachers' self-efficacy beliefs as determinants of job satisfaction and students' academic achievement: A study at the school level, Journal of School Psychology, 44(6), 473-490.

Chen, W. (2007). The structure of secondary school teacher job satisfaction and its relationship with attrition and work enthusiasm. Chinese Education and Society, 40(5), 17-31.

Coladarci, T. (1992). Teachers' sense of efficacy and commitment to teaching. Journal of Experimental Education, 60, 323-337.

Cubukcu, F. (2008). A study on the correlation between self efficacy and foreign language learning anxiety. Journal of Theory and Practice in Education, 4(1), 148-158.

DeMesquita, P.B., \& Drake, J. (1994). Educational reforms and the self-efficacy beliefs of teachers 
implementing nongraded primary school programs. Teaching and Teacher Education, 10(3), 291-302.

DaCosta, J.L., \& Riordan, G. (1996). Teacher collaboration: developing trusting relationship. Paper prepared for presentation at the XXIV CSSE Annual Meeting, St. Catharines, Ontario.

Elliott, E.M., Isaacs, M.L., \& Chugani, C.D. (2010). Promoting self-efficacy in early career teachers: A principal's guide for differentiated mentoring and supervision. Florida Journal of Educational, 4(1), 131-146.

Evans, E.D., \& Tribble, M. (1986). Perceived teaching problems, selfefficacy and commitment to teaching among pre-service teachers. Journal of Educational Research, 80, 81-85.

European Commission-Eurydice (2015). The Teaching Profession in Europe: Practices, Perceptions, and Policies. Eurydice Report. Luxembourg: Publications Office of the European Union.

Gavora, P. (2010). Slovak pre-service teacher self-efficacy: theoretical and research considerations. The New Educational Review, 21(2), 17-30.

Geiser, C. (2013). Data analysis with Mplus. New York: Guilford Press.

Guskey, T.R. (1988). Teacher efficacy, self-concept, and attitudes toward the implementation of instructional innovation. Teaching and Teacher Education, 4, 63-69.

Guskey, T.R., \& Passaro, P.D. (1994). Teacher efficacy: A study of construct dimensions. American Educational Research Journal, 31, 627-643.

Henson, R.K. (2001). Teacher self efficacy: Substantive implications and measurement dilemmas. Paper presented at the Annual Meeting of the Educational Research Exchange, Texas.

Hoover-Dempsey, K.V., Bassler, O.C., \& Brissie, J.S. (1992). Explorations in parent-school relations. Journal of Educational Research, 85(5), 287-294.

Hoy, W.K., \& Woolfolk, A. (1993). Teachers' sense of efficacy and the organizational health of schools. Elementary School Journal, 93(4), 355-372.

Izadinia, M. (2014). Teacher educators' identity: a review of literature. European Journal of Teacher Education, 37(4), 426-441.

Kiviet, A.M., \& Mji, A. (2003). Sex differences in self-efficacy beliefs of elementary science teachers. Psychological Reports, 92(1), 333-338.

Klassen, R.M., \& Chiu, M.M. (2010). Effects on teachers' self-efficacy and job satisfaction: Teacher gender, years of experience, and job stress. Journal of Educational Psychology, 102(3), 741-756.

Labone, E. (2004). Teacher efficacy: Maturing the construct through research in alternative paradigms. Teaching and Teacher Education, 20, 341-359.

Lewandowski, K.H.L. (2005). A study of the relationship of teachers' selfefficacy and the impact of leadership and professional development [PhD Thesis]. Indiana: University of Pennsylvania. Retrieved from: http:// bit.ly/2knaSdq

Mahmoee, H.M., \& Pirkamali, M.A. (2013). Teacher self-efficacy and students' achievement: A theoretical overview. The Social Sciences, 8, 196-202.

Midgley, C., Feldlaufer, H., \& Eccles, J.S. (1989). Change in teacher efficacy and student self- and task- 
related beliefs in mathematics during the transition to junior high school. Journal of Educational Psychology, 81(2), 247-258.

Muthén, B.O. (1994). Multilevel covariance structure analysis. Sociological Methods \& Research, 22(3), 376-398.

Muthén B.O., Khoo S.T., \& Gustafsson J.E. (1997). Multilevel latent variable modelling in multiple populations. Retrieved from http://bit.ly/2knJBrb

Muthén, L.K., \& Muthén, B.O. (19982010). Mplus user's guide, $6^{\text {th }}$ Edition. Los Angeles, CA: Muthén \& Muthén.

OECD (2009). Creating effective teaching and learning environments: First results from TALIS, Paris: OECD.

OECD (2013). Teaching and learning international survey TALIS 2013. Conceptual framework. Retrieved from: http://bit.ly/1n5G52h

OECD (2014a). TALIS 2013 results. An international perspective on teaching and learning. Paris: OECD.

OECD (2014b). TALIS 2013 Technical report. Retrieved from: http://bit. ly/2jR57Uz

Pendergast, D., Garvis, S., \& Keogh, J. (2011). Pre-service student-teacher self-efficacy beliefs: An insight into the making of teachers. Australian Journal of Teacher Education, 36(12), 46-58.

Phillips, D., \& Schweisfurth, M. (2014). Comparative and international education: An introduction to theory, method, and practice. London: Bloomsbury.

Prieto, L. (2005). Las creencias de autoeficacia docente del profesorado universitario [Tesis doctoral]. Madrid: Universidad Pontificia Comillas.
Ross, J.A. (1995). Beliefs that make a difference: The origins and impacts of teacher efficacy. Paper presented at the Annual Meeting of the Canadian Association for Curriculum Studies, Alberta, Canada. Retrieved from: http://bit.ly/2jzeUuK

Ross, J., \& Bruce, C. (2007). Professional development effects on teacher efficacy: Results of randomised field trial. The Journal of Educational Research, 101(1), 50-60.

Ross, J., Bradley, J., \& Gadalla, T. (1996). Within-teacher predictors of teacher efficacy. Teaching and Teacher Education, 12(4) 385-400.

Scheerens, J. (2010). Teachers' Professional Development: Europe in international comparison. An analysis of teachers' professional development based on the OECD's Teaching and Learning International Survey (TALIS). Luxembourg: Office for Official Publications of the European Union.

Snijders, T.A., \& Bosker, R.J. (1994). Modeled variance in two-level models. Sociological Methods \& Research, 22(3), 342-363.

Tschannen-Moran, M., \& Hoy, A.W. (2001). Teacher efficacy: Capturing an elusive construct. Teaching and Teacher Education, 17, 783-805.

Van den Berg, R. (2002). Teachers' meaning regarding educational practice. Review of Educational Research, 72, 577-625.

Wheatley, K.F. (2005). The case for reconceptualizing teacher efficacy research. Teaching and Teacher Education, 21, 747-766. 


\section{PERFIL ACADÉMICO Y PROFESIONAL DE LOS AUTORES}

Inmaculada Egido Gálvez. Doctora en Ciencias de la Educación, con Premio Extraordinario de Doctorado, por la Universidad Nacional de Educación a Distancia. Profesora Titular de Universidad acreditada como Catedrática en el Departamento de Teoría e Historia de la Educación de la UCM. Sus líneas de investigación se centran en el ámbito de la Política Educativa Comparada. Es presidenta de la Junta Directiva de la Sociedad Española de Educación Comparada.

Esther López-Martín. Licenciada en Pedagogía (Premio extraordinario) por la Universidad Complutense de Madrid y Doctora en Ciencias de la Educación con mención de «Doctor Europeo» (Premio extraordinario) por esta misma universidad. Actualmente, es profesora del Departamento MIDE II de la UNED y miembro del Grupo de Investigación Medida y Evaluación de Sistemas Educativos de la UCM y del Grupo de Investigación en Sistemas de Orientación Psicopedagógica y Competencias de los Orientadores de la UNED.

Jesús Manso. Diplomado en Magisterio de Educación Especial, Licenciado en Psicopedagogía (Premio extraordinario y Premio Nacional a la Excelencia Académica), Máster en Mejora y Calidad de la Educación por la Universidad Autónoma de Madrid (UAM) y Doctor en Ciencias de la Educación con mención de «Doctor Europeo» por esta misma universidad. Profesor del Departamento de Didáctica y Teoría de la Educación de la UAM y miembro del Grupo de Investigación sobre Políticas Educativas Supranacionales.

Javier M. Valle. Profesor Titular de la UAM. Director del Grupo de Investigación reconocido de la UAM sobre «Políticas Educativas Supranacionales»(GIPES). Asesor externo de EURYDICE. Miembro de TEAM-EUROPE. Miembro de la Junta Directiva de la Sociedad Española de Educación Comparada. Miembro de la Sociedad Española de Pedagogía y de la Comparative Education Society in Europe. Co-Director de la Journal of Supranational Policies of Education, y Co-Director de la Revista Española de Educación Comparada.

Dirección de los autores: Inmaculada Egido Gálvez

Universidad Complutense de Madrid

Facultad de Educación. Desp. 3207

C/ Rector Royo Villanova, s/n

28040 Madrid

E-mail: miegido@ucm.es 


\author{
Esther López-Martín \\ UNED \\ Facultad de Educación \\ Dpto. MIDE II. Despacho 2.79 \\ C/ Juan del Rosal, 14 \\ 28040 Madrid \\ E-mail: estherlopez@edu.uned.es \\ Jesús Manso, Javier M. Valle \\ Universidad Autónoma de Madrid \\ Facultad de Form. Prof. y Educación \\ Avda. Tomás y Valiente, 3 \\ 28049 Madrid \\ E-mail: jesus.manso@uam.es \\ jm.valle@uam.es
}

Fecha Recepción del Artículo: 13. Enero. 2016

Fecha modificación Artículo: 18. Octubre. 2016

Fecha Aceptación del Artículo: 21. Noviembre. 2016

Fecha Revisión para Publicación: 22. Febrero. 2018 